\title{
Erratum: Does the New Testament support Christian Zionism?
}

\section{Author:}

Philip La Grange Du Toit ${ }^{1}$

\section{Affiliation:}

${ }^{1}$ Faculty of Theology,

Stellenbosch University,

South Africa

\section{Corresponding author:}

Philip La Grange Du Toit,

plgdutoit@gmail.com

Dates:

Published: 21 Dec. 2017

How to cite this article: Du Toit, P. La G., 2017,

'Erratum: Does the New

Testament support Christian

Zionism?', In die Skriflig 51(1),

a2334. https://doi.org/

10.4102/ids.v51i1.2334

\section{Copyright:}

C 2017. The Authors.

Licensee: AOSIS. This work

is licensed under the

Creative Commons

Attribution License.
In the version of this article initially published, the surname of Philip La Grange Du Toit was incorrectly listed as La Grange Du Toit in the 'How to cite this article' section. His correct surname is $\mathrm{Du}$ Toit.

The 'How to cite this article' section has been corrected as follows:

How to cite this article:

Du Toit, P. La G., 2016, 'Does the New Testament support Christian Zionism?', In die Skriflig 50(1), a2164. http:/ /dx.doi.org/10.4102/ids.v50i1.2164

The error has been corrected in the PDF version of the article. The publisher apologises for any inconvenience that this may have caused. 